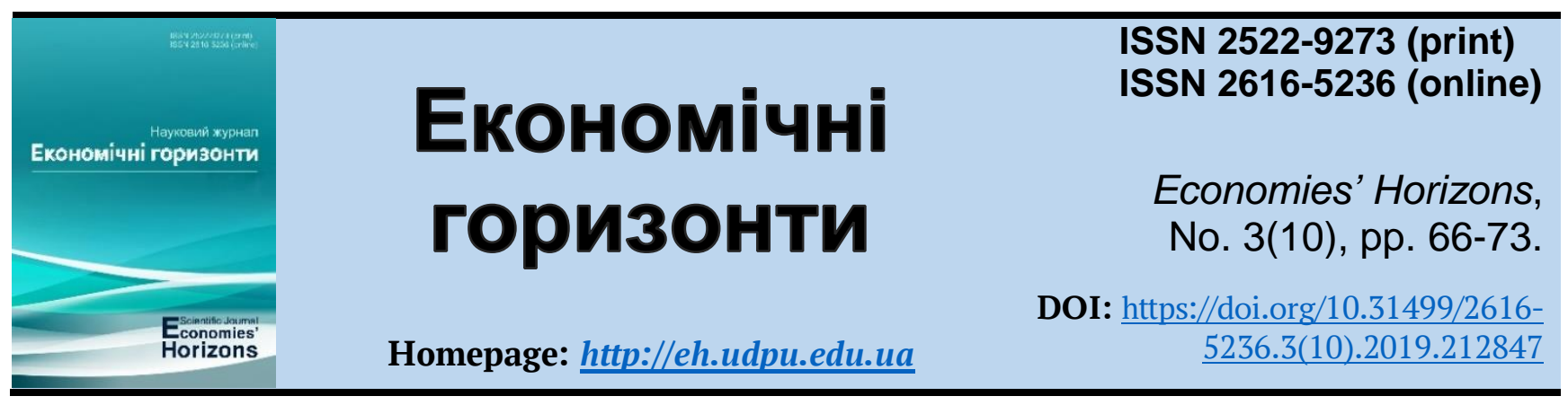

UDC 330.322 .3

\title{
Investment aspects of event tourism development: national and regional dimension
}

\author{
Tetyana V. Stroiko ${ }^{1}$, Doc. Ec. Sc., Professor \\ Vlada O. Lazarenko ${ }^{2}$
}

Received: 23 July 2019

Accepted: 30 August 2019
Stroiko, T. V. and Lazarenko, V. O. (2019), "Investment aspects of event tourism development: national and regional dimension", Economies' Horizons, no. 3(10), pp. 6673, doi: https://doi.org/10.31499/2616-5236.3(10).2019.212847

Abstract. The purpose of the article. The aim of the article is to formulate the investment aspects of event tourism development in national and regional areas. Methodology. In the research general science methods such as generalization and comparison were used. It was made for analyzing scientists' views in connection with event tourism. Results. In the article theoretical essence of event tourism was analyzed. Also interrelation between event tourism and event management including a complex of actions such as planning, organization, control and realization of different events and activities for the purpose of popularization of the specific event and territory was highlighted. The basic specific features of event tourism were identified. The necessity of establishing a system of constant monitoring of the situation and introduction of measures to form preconditions for reducing the negative factors influence were substantiated. The value of market research connected with the changes in geospatial vectors of tourist flows to respond quickly to customers' needs and in order to meet an effective consumer demand, the development of strategic measures to restore and evolve tourism were justified. Practical meaning. It is determined that event tourism is an important element of the tourism services structure. The novelties always have the biggest demand in every area of human activity. Accordingly, event tourism can become the main feature of the region. It can provide a regular tourists flow and it means higher income, which fixes the base of its social and economic development. It was underlined that the main condition of the domestic tourism development in Ukraine is the creation of a favorable investment climate and transparent legislation. It was defined that nowadays Ukrainian tourist market is too chaotic. Because of the disorder of tourist market tour operators, hotels and tourists have many problems. They include invalid licenses, imperfect categorization of accommodation facilities, unsystematic activities of travel agencies and guides. It is necessary to install clear and easy working rules in order to act effectively in the tourist market. Prospects for further research. It is proved that the formation of effective legislation with changes in relevant laws has to become the basis for event tourism development in the country and the regions. And only after that it is possible to speak about infrastructure development and investment attraction to this sector of economy. It is necessary to form new tourist products in the regions. Only in one complex all these points will become the base of tourist territories development on the condition that local businesses and communities will be involved.

\footnotetext{
${ }^{1}$ Mykolaiv V. O. Sukhomlynskyi National University; Head of the Department of Economics and Management; ORCID ID: https://orcid.org/0000-0002-0044-4651; e-mail: tanyastroyko@gmail.com.

${ }^{2}$ Mykolaiv V. O. Sukhomlynskyi National University; student; ORCID ID: https://orcid.org/0000-0002-91547356; e-mail: vlada.lazarenko@ukr.net.
} 
Keywords: tourism, event tourism, investment, socio-economic development of regions, supply and demand.

JEL Classification: G31, L83, R53, Z32.

Number of references: 12; number of tables: 1; number of figures: 0; number of formulas: $\mathbf{0 .}$

\title{
Інвестиційні аспекти розвитку івент-туризму: національний та регіональний вимір
}

\author{
Тетяна Володимирівна Стройко ${ }^{1}$, д. е. н., професор \\ Влада Олександрівна Лазаренко ${ }^{2}$
}

Стаття надійшла: 23.07.2019 Стаття прийнята: 30.08.2019
Stroiko T. V., Lazarenko, V. O. Investment aspects of event tourism development: national and regional dimension. Економічні горизонти. 2019. № 3(10). C. 66-73. DOI: $10.31499 / 2616-5236.3(10) \cdot 2019.212847$

Анотація. Метою статті $\epsilon$ визначення інвестиційних аспектів розвитку івент-туризму на національному та регіональному рівнях. Методологія. У досліджені застосовані загальнонаукові методи, зокрема узагальнення, порівняння - для аналізу поглядів науковців щодо сутності івент-туризму. Результати. В роботі було проаналізовано теоретичну сутність івент-туризму та його взаємозв'язок з формуванням івент-менеджменту як комплексу дій з планування, організації, контролю та проведення різних подій та заходів з метою популяризації конкретної подій та території. Визначено основні специфічні особливості івент-туризму. Обгрунтовано необхідність налагодження системи постійного моніторингу ситуації, запровадження заходів із формування передумов зменшення сили впливу негативних чинників, ринкових досліджень змін геопросторових векторів туристських потоків для швидкого реагування на потреби та задоволення відкладеного платоспроможного попиту споживачів, розроблення стратегічних заходів відновлення $\mathrm{i}$ розвитку туристичної діяльності підприємств. Практичне значення. Встановлено, що івентивний туризм являється важливою ланкою у структурі туристичних послуг. У кожній сфері діяльності людини саме новинки користуються найбільшим попитом. Відповідно, саме івентивний туризм може стати основною особливістю регіону, що в змозі забезпечити регулярний потік відвідувачів, а значить і доходів, закріплюючи тим самим підгрунтя його соціально-економічного розвитку. Визначено, що основною умовою розвитку внутрішнього туризму в Україні є створення сприятливого інвестиційного клімату та прозорого законодавчого поля. Адже український туристичний ринок сьогодні досить хаотичний. Від невпорядкованості туристичного ринку страждають і туроператори, і готелі, і самі туристи. Недієві ліцензії, недосконала категоризація засобів розміщення, безсистемна діяльність туристичних агентств та гідів, тощо. Для ефективної роботи туристичного ринку, залучення інвестицій необхідно встановити чіткі та прості до виконання правила роботи. Перспективи подальших досліджень. Обгрунтовано, що базисом для розвитку івент-туризму в країні та їі регіонах повинно стати формування дієвого правового поля, з внесенням змін до відповідних законів. І вже як наслідок розбудова інфраструктури та залучення інвестицій до цього сектора економіки. Необхідно формувати формувати нові туристичні продукти в регіонах. Все це в комплексі стане основою розвитку всіх туристичних територій за умови залучення місцевого бізнесу та громад.

Ключові слова: туризм, івент-туризм, інвестиції, соціально-економічний розвиток регіонів, попит та пропозиція.

Кількість джерел: 12; кількість таблиць: 1; кількість рисунків: 0; кількість формул: 0.

\footnotetext{
${ }^{1}$ Миколаївський національний університет імені В. О. Сухомлинського; завідувач кафедри економіки та менеджменту; ORCID ID: https://orcid.org/0000-0002-0044-4651; e-mail: tanyastroyko@gmail.com.

${ }^{2}$ Миколаївський національний університет імені В. О. Сухомлинського; студентка; ORCID ID: https://orcid.org/0000-0002-9154-7356; e-mail:vvlada.lazarenko@ukr.net.
} 


\section{Introduction.}

Event tourism has become a very popular area in the world tourism industry in recent decades. The most important characteristic feature of event tourism is timing of a tourist trip to a certain event, festival or entertainment. It can be music competitions, national festivals and carnivals, theatrical performances, various competitions and championships, political actions, unique natural phenomena, which have the ability to attract visitors to the places where they occur.

In today's globalized world, event-tourism is becoming more and more popular. Events are embedded into the existing sociocultural landscape of the territory, while differing in their versatility, a variety of bright unique moments.

All the planned events are made with specific goals. Also they are an area of activity for one person or community. Not so far it has become a business and one of the reasons of investment is the attractiveness of certain objects and territories. That's why research of investment for event tourism is an actual problem, which needs a comprehensive and thorough research.

\section{Literature review.}

The problems of event tourism development are researched by many scientists such us O. Babkin (2008), O. Vlasenko (2014), S. Saidmamedova and I. Solovieva (2017), M. Sonder (2006), N. Kirkup and M. Sutherland (2017), L. Todd, A. Leask and J. Ensor (2017), H.-W. Lin and H.-F. Lu (2017), K. Backman (2018), S. Berezka, M. Kolkov and E. Pereskokova (2018), I. Parkhomenko (2018). External and internal factors influencing the development and investment attractiveness of event tourism are diverse and multifaceted. That's why they need more complex researches.

\section{Methodology.}

The theoretical and methodological basis of the study are scientific papers in the field of housing and communal services of urban agglomerations. To achieve the purpose of the article, the following research methods were used: theoretical generalization - to determine the theoretical foundations and trends in the content and components of modeling the relationship between utilities and partners; system approach - to generalize the forms of relationships between utilities and partners; methods of positive and normative analysis to develop recommendations for improving the modeling of the relationship between utilities and partners.

\section{Research objectives.}

The aim of this article is to research the investment aspects of event tourism development in the national and regional areas.

\section{Results and discussions.}

It should be noted that nowadays tourism is a complex system. Accordingly, this tourist industry is making significant contribution to the development of the national economy of the country and its regions.

Basically, the tourism sector is seen as a specific and attractive sector of the economy. It is also positioned as an important component of the modern state and regional policy, which significantly affects the socio-economic development of the country. Tourism sector also has an impact on the image of the country at the international level.

The active actions of the world community in the field of organizing events have led to the emergence of the event tourism, which has been developing dynamically in recent years. Its main task is to plan and hold largescale events in the areas of education, sports, cultural and entertainment events. All these events can attract tourists to places where the event is taking place. Thus, different places become more popular at the state and international levels. That's why event tourism is an important detail in making positive image of the region. It happens because socio-economic development becomes better after the popularization of the region by the tourist flow.

O. Babkin says that event tourism is a promising and dynamically developing type of tourism with a festive atmosphere, individual conditions of rest and unforgettable impressions. The main feature of event tourism is the variety of bright unique moments (Babkin, 2008).

A. Durovich says that event tourism is such a kind of tourism when tourists become witnesses of great events in the world of sports, culture and art (Durovich, 2003). 
A characteristic feature of event tourism is timing the trip to a specific event, holiday, festival. It can be music competitions, national festivals and carnivals, theatrical performances, various competitions and championships, political actions. The history of the event tourism started when Olympic Games in Ancient Greece appeared, when thousands of interested people from all over the Mediterranean were brought together.

Nowadays the importance of the leisure industry has become much more significant. In the national economy of Ukraine, the tourism industry management has begun to be transferred into its every region, decentralization in management and expansion of the region's rights to develop service markets are growing in parallel with the growth of their responsibility for tourism, environmental and financial elements of the regional system.

It happens because the development of a tourism area is a popularization of the region in the world and after that increasing the investment attractiveness of the region. Extra budget revenues are of particular importance. It is worth noting that these are additional budget revenues and new jobs, which reduce unemployment rate in the country and its expenditures. These points increase the level of well-being and quality of life throughout the country, not only in one region.

The developing tourism industry has formed a specific area of management. O. Vlasenko claims that "nowadays event management has become the subject of study and the area of application of practical skills and abilities, which aimed at the development, production and management of the planned events, meaningful festivals, celebrations, entertainment events, recreational events, political, state, scientific and theatrical events' in his work. Event management as a separate area of research in modern science" (Vlasenko, 2014).

For example, S. Saidmamedova and I. Solovyova explain the event management as all the actions which are provided with planning, organizing, controlling and conducting of a special event in order to attract the target audience to their products and services by positioning the company in the market as an expert (Saidmamedova and Solovyova, 2017).

M. Sonder in his works characterizes event management as "a set of measures to create corporate and mass events, the task of which is to make a regular event a unique event that will be remembered by the target audience" (Sonder, 2006).

I. Parkhomenko explains the meaning of event management as "a complex of pre-defined measures in order to conduct the event effectively" (Parkhomenko, 2018).

Therefore, it should be defined that event management is a complex of measures such as planning, organizing, controlling and conducting various events and activities in order to promote a specific event and territory.

Modern event management includes a wide range of marketing influence resources (from bringing simple but important information to employees and customers to effective representation of a brand or a product). It is implemented by organizing various events. Limits of influence can be different too. It can be one firm, a few organizations or significant territorial communities. The main levers for the development of event management are the results of activities and profit from their implementation.

The main functions of event management are planning, organizing and controlling the event. The uniqueness of this event is not only in a new idea, but in the methods of bringing it to the consumer.

One of the most important factors for a spectacular event is the successful choice of the place where the event will take place, its plan, participants and subordinates. It is at the stage of organization that the above mentioned issues are resolved. As soon as the event begins, a control function begins for the event manager, the essence of which is to monitor all the elements that are provided by the script.

Talking about the economic efficiency of event management, it should be underlined that this area is in the process of development in our country now. The quality of services provided is gradually increasing. Their scale is expanding. Pricing policy of organizations is 
more flexible. Prices have become more affordable, but, nevertheless, there are several problems that hinder the development of this area.

The major challenges of the event management development are unpreparedness of the population for creative and decisive actions and insufficient number of qualified specialists in the market. Every year the relevance of event management grows, that's why there are more and more companies that specialize in this. This leads to rapid growth of competition, which has a positive effect on the market.

The tourism industry should be considered as one of the most promising for Ukraine in European integration processes. And, most importantly, this industry is a promising currency-forming sphere of economic activity. It needs setting up a system of constant monitoring of the situation, the introduction of measures to reduce the impact of negative factors, market research changes in geospatial vectors of tourist flows to respond quickly to needs and to meet the effective consumer demand, the development of strategic measures to restore and develop the tourism activities of enterprises.

Every year the sphere of tourism develops and gains more and more momentum in Ukraine. According to the State Statistics Committee of Ukraine, about 14 million foreigners come to our country every year. Most of them are from the CIS countries, and a third of them are from the EU. The number of foreign citizens who crossed the state border of Ukraine during the period 2016-2019 is presented in Table 1.

Table 1. Number of foreign citizens crossing the state border of Ukraine (thousands)

\begin{tabular}{|l|c|c|c|c|c|c|c|}
\hline \multirow{2}{*}{ Quarters } & \multirow{2}{*}{$\mathbf{2 0 1 6}$} & \multirow{2}{*}{$\mathbf{2 0 1 7}$} & \multirow{2}{*}{$\mathbf{2 0 1 8}$} & \multirow{2}{*}{$\mathbf{2 0 1 9}$} & \multicolumn{3}{c|}{ Growth, \% } \\
\cline { 6 - 8 } & & & & & $\mathbf{1 7 / 1 6}$ & $\mathbf{1 8 / 1 7}$ & $\mathbf{1 9 / 1 8}$ \\
\hline I quarter & $2,427.3$ & $2,631.5$ & $2,547.7$ & $2,357.8$ & +8.4 & -3.2 & -7.5 \\
\hline II quarter & $3,392.7$ & $3,697.1$ & $3,673.4$ & $3,513.8$ & +9.0 & -0.6 & -4.3 \\
\hline III quarter & $4,559.5$ & $4,769.5$ & $4,935.7$ & - & +4.6 & +3.5 & - \\
\hline IV quarter & $3,226.3$ & $3,323.1$ & $3,050.1$ & - & +3.0 & -8.2 & - \\
\hline Total & $\mathbf{1 3 , 6 0 6 . 0}$ & $\mathbf{1 4 , 4 2 1 . 2}$ & $\mathbf{1 4 , 2 0 7 . 0}$ & - & $+\mathbf{6 . 0}$ & $\mathbf{- 1 . 5}$ & - \\
\hline
\end{tabular}

Source: The Ministry of Economic Development, Trade and Agriculture of Ukraine (2019).

The ongoing financial and economic crisis in Ukraine, the events related to the annexation of the Autonomous Republic of Crimea and the events in the east of the country have negatively affected the incoming tourist flow, the tourism structure and the tourism opportunities of the country in the domestic and foreign tourist markets. The data for 2019 are presented only for the first two quarters. It should be noted that the number of visitors in 2017, 2018 is much higher than in 2016. This may be due to the fact that tourists understand the fact that despite the military conflict in the country, it remains a relatively safe country to visit. It is known that according to the analysis conducted by the World Tourism Organization, Ukraine occupies an important place in the annual number of visits.

From the above mentioned facts it is necessary to conclude that the tourism industry has been and remains extremely important for the development of Ukraine's economy, and the development of this area for the citizens' public life must be a priority for the nearest future.

The main trends in the volume of tourist flows in Ukraine can be explained by two main factors. Firstly, political instability, anti-terrorist operation, the declining of the solvency of the population have caused an objective precondition for the reduction of tourist flows and tourist activity of the population of the state, region and tourist attractiveness of the country for foreign visitors. It has led to the increased competition among enterprises - manufacturers of tourism products in Ukraine and the excess of supply over the consumption of tourism services. Secondly, the actual reduction of tourist flows is also due to the lack of reliable data from the Autonomous Republic of Crimea and parts of the Donetsk and Luhansk regions. According to statistics it is possible to 
conclude that the citizens who cross the state border of Ukraine the most are from Moldova, Belarus, Russia, Poland, Hungary, Romania, Slovakia and Turkey.

Analyzing the regions separately, according to the statistics of tour operators, the geography of visits of foreign tourists includes the Transcarpathian region, the Odessa and Kharkiv regions (the latter as an object of business tourism). Domestic tourism is concentrated in the Kyiv, Lviv, Poltava, Cherkasy and Dnipropetrovsk regions.

Talking about the Mykolaiv region it is necessary to say that this region has extremely many unused tourist and recreational resources. That's why this region is one of the most perceptive regions for the development of the tourism sector in Ukraine. The rich potential and opportunities of this region form the sea coast (the access to the Black Sea). The Mykolaiv region has a clean environment in comparison with other regions of the country. Also an important element is the cultural and historical heritage of the Mykolaiv region. There are a large number of primitive settlements, which were found in this region.

There are more than 200 health and sanatoriums in the region. In the Mykolaiv region sanatoriums and boarding houses of rest are situated, too. About 50 hotels operate in the cities of the Mykolaiv region.

But despite all advantages of the Mykolaiv region in the field of tourism, there are a number of the reasons which prevent its regional development. The main factors are inadequate state policy, low level of development of tourism infrastructure and material base, which are still at a low level.

There are many untouched natural objects in the territory of the Mykolaiv region, which could become popular tourist objects and would attract many visitors both from Ukraine and abroad. Active involvement of tourists will have a positive impact on the development of the country's economy. The most popular objects are the farmstead "Ostryvets" (the Voznesenskyi district), the Ostrich farm "Kremenovskyy ostrich" (the Veselinovskyi district), the museum complex of Cossack glory and military equipment ( $\mathrm{Yu}$ zhnoukrainsk city), thresholds (Voznesensk city), Migiya (the Pervomayskyi region).

Green tourism is no less promising for the tourism development in the region. It means the revival and the development of traditional Ukrainian culture, namely folk architecture and art, various crafts that are part of the local flavor. This kind of recreation represents Ukraine to other countries, as well as attracts foreign tourists by preserving the ethnographic identity of the Ukrainian people.

As a prerequisite for the successful development of recreation in rural ethnographic areas, the formation of ideology of revival and development of the whole spectrum of traditional culture, from forms of economic activities to the spiritual sphere, should be considered, which will act as favorable factors for individual recreation in ethnographic regions of Ukraine. Thus, due to the green tourism the economy of the region will be strengthened.

For these reasons, it is necessary to develop and improve the available tourist resources of the region, to attract Ukrainian and foreign investors to improve the objects visited and not to forget about such an important element as conducting an advertising campaign both for the residents of Ukraine and for the international market of tourist services.

Speaking about the event tourism, which is narrower concept than "tourism", it should be mentioned that, in order to popularize the Mykolaiv region as an attractive territory for tourism and recreation, various festivals and other mass events in the most popular places of the region regularly take place. That's because such events are designed to interest adults, children and youth.

Thus, regarding the essence of event tourism, it should be noted that event tourism is an important link in the structure of tourist services. In every sphere of human activity it is the novelty that is most in demand. Such products and services are those that are original, interesting, spectacular, such as have never been before and will not be repeated in the future. To sum up, we can conclude that it is the event tourism that can become the main 
feature of the region, which is able to provide a regular flow of visitors. After that, incomes will increase. It will be the basis of its socioeconomic development.

The brightest examples of the sphere of event tourism of the Mykolaiv region are the following annual festivals:

"Rest actively!", which is held in the area of the rocky massif of the Southern Bug River near Yuzhnoukrainsk city. This event includes competitions in mountain sports tourism, competitions in orienteering, rock jumping, excursions and hikes, a tourist entertainment, a concert-competition of bard songs, a culinary competition of marching cuisine, demonstration performances of folk crafts and a club of a historical reconstruction;

The Olbia Festival is held on the territory of the Olbia National Historical and Archaeological Reserve on the shores of the DnieperBug estuary. The program includes a bicycle race Mykolaiv - Parutine, excursions on the earth of ancient Olbia, tasting of foodstuff of the Ukrainian manufacturers, acquaintance with the Indian national cuisine, exhibitionssales of works of artists and products of national crafts. And, of course, an evening gala concert of author's song and acoustic music with the participation of performers and groups of Mykolaiv, Kyiv, Kharkiv and Odessa;

Cossack festival "Mihiyska Sich”, which is held in the village of Mihiya, the Pervomaisky region. The purpose of the event is to honor the heroes of Ukraine from the times of the Cossacks to the present. The festival program includes meetings with anti-terrorist operation veterans, master classes, a fair, sports trainings, trainings-lectures, a meeting with writers, Cossack entertainments, excursions. The culmination is rafting and a rock concert, as Mihiya is called the "capital of Ukrainian rafting" and "little Switzerland". The participants of the event live in tents. They can get the skills in making pottery, embroidery, they can also get acquainted with Petrykivka painting. The participants can be engaged in military-tactical and pre-medical training.

The festivals and events of this type are aimed at promoting the region in the world, and, as a consequence, increasing the level of investment attractiveness of the region through the formation of a positive tourist image of the territory. No less important consequences of the development of event tourism in the region are additional revenues to the budget, positive emotions of service users. Also, it is new working places, which reduces the unemployment rate in the country and expenditures for it. These points increase the level of well-being and quality of life throughout the country, not only in one region.

It is important to note that the development of event tourism of the Mykolaiv region is actively promoted by its geopolitical location, ethnic composition of the population, diversity of folk culture, features of traditions and customs.

Moreover, event tourism in the Mykolaiv region stimulates the development of hotel and restaurant business of the region. This is due to the fact that during the festival or event there is almost complete occupancy of the hotels and hostels in a particular region.

Usually low demand is an obstacle to sustainable development of event tourism. Most often such situation happens because our state insufficiently supports and insufficiently finances the development of such modern, perspective type of tourism in the territory of the Mykolaiv region and Ukraine as a whole.

No less important factor in the development of event tourism is the appropriate organization of event tours by travel agencies, their awareness and interest in the opportunities of the region, restaurants and participants' accommodation, advertising events in time, providing relevant information to service consumers. In the Mykolaiv region travel agencies work very productively because long before the event, people have the opportunity to get acquainted with the program of the festival or event, book and buy tickets, etc.

Nowadays, event tourism in the Mykolaiv region is beginning to develop and is becoming increasingly popular due to the emergence of a large number of regional and local events. Periodically, there are events dedicated to a particular holiday or theme that attract people from all over the country, and sometimes even foreigners. 


\section{Conclusions.}

The main condition for the development of domestic tourism in Ukraine is the creation of a favorable investment climate and transparent legislation. After all, the Ukrainian tourist market today is quite chaotic. Tour operators, hotels, and tourists themselves suffer from the disorder of the tourist market. It includes invalid licenses, imperfect categorization of accommodation, unsystematic activities of travel agencies and guides. For the effective operation of the tourism market and attracting investment, it is necessary to establish clear and simple rules of operation.

All this requires changes to the law of
Ukraine "On Tourism" and relevant regulations. Another key aspect is infrastructure development and investment attraction. Today Lviv, Kyiv and Odessa are fully ready to receive foreign tourists. But it is necessary to form new tourist products in the regions. There will be demand - there will be supply. And the infrastructure will be updated along these routes. Investors will invest, build hotels, restaurants and attractions.

Thus, the new transparent rules, investment climate and infrastructure will be the basis for the development of all tourist areas. And it is possible only with the involvement of local businesses and communities.

\section{References}

Babkin, O. V. (ed.) (2008), Spetsial'nye vidy turizma [Special types of tourism], Feniks, Rostov-on-Don, Russia, $252 \mathrm{p}$.

Backman, K. F. (2018), "Event management research: The focus today and in the future", Tourism Management Perspectives, vol. 25, pp. 169-171. doi: https://doi.org/10.1016/j.tmp.2017.12.004

Berezka, S., Kolkov, M. Y. and Pereskokova, E. V. (2018), "The development approaches to tourist value propositions of small cities: The case of the Vladimir Region", Worldwide Hospitality and Tourism Themes, vol. 10, no. 4, pp. 498-509. doi: https://doi.org/10.1108/WHATT-03-2018-0018

Durovich, A. P. (2003), Marketing v turizme [Tourism Marketing], Novoe znanie, Minsk, Belarus, 496 p.

Kirkup, N. and Sutherland, M. (2017), "Exploring the relationships between motivation, attachment and loyalty within sport event tourism", Current Issues in Tourism, vol. 20, no. 1, pp. 7-14. doi: https://doi.org/10.1080/13683500.2015.1046819

Lin, H.-W. and Lu, H.-F. (2016), "The evaluation of event sport tourism on regional economic development", International Journal of Economics and Management Engineering, vol.11, no. 1, pp. 38-48. doi: https://doi.org/10.5281/zenodo.1128060

Parkhomenko, I. I. (2018), "UK scientific tradition in Events Management: key concepts (G. Bowdin, H. Pielichaty, G. Els)", Bulletin of Kyiv National University of Culture and Arts. Series in Management of Social and Cultural Activity, no. 2, pp. 63-76. doi: https://doi.org/10.31866/2616-7573.2.2018.149459

Saidmamedova, S. and Solovyova, I. A. (2017), “Event-management in the socio-cultural sphere”, Studencheskii nauchnyi forum [Student Scientific Forum], Materialy IX Mezhdunarodnoi studencheskoi nauchnoi konferentsii [Materials of the IX International Student Scientific Conference], Moskow, Russia, March 3031, 2017, pp. 105-107. available at: https://files.scienceforum.ru/pdf/2017/32913.pdf (Accessed 15 Julay 2019).

Sonder, M. (2006), Ivent-menedzhment: organizatsiya razvlekatel'nykh meropriyatii. Tekhniki, idei, strategii, metody [Event management: organization of entertainment events. Techniques, ideas, strategies, methods.], Vershina, Moscow, St. Petersburg, Russia, 544 p.

The Ministry of Economic Development, Trade and Agriculture of Ukraine (2019), "Information on the visit to Ukraine by foreign tourists and citizens of Ukraine traveling abroad and half years 2016-2019", available at: https://me.gov.ua/Documents/Download?id=13fa3ae9-19e7-42a7-8feb-ebdab617d977 (Accessed 15 Julay 2019).

Todd, L., Leask, A. and Ensor, J. (2017), “Understanding primary stakeholders' multiple roles in hallmark event tourism management", Tourism Management, vol. 59, pp. 494-505. doi: https://doi.org/10.1016/j.tourman.2016.09.010

Vlasenko, O. B. (2014), "Event management as a separate line of research in modern science”, Scientific Bulletin of Kherson State University. Series "Economic Sciences", vol. 9, no. 3, pp. 142-145.

Цей твір ліцензовано на умовах Ліцензії Creative Commons «/з Зазначенням Авторства - Некомериійна 4.0 Міжнародна» (CC BY-NC 4.0).

This is an open access journal and all published articles are licensed under a Creative Commons "Attribution-NonCommercial 4.0 International" (CC BY-NC 4.0). 